\title{
A study on the optimal conditions for latent fingerprint development using cyanoacrylate fuming method in vacuum chamber
}

\author{
Je-Seol Yu ${ }^{\star}$, jin-Sung Jung, Seung Lim ${ }^{1}$ and Sung-Woo Park ${ }^{2}$ \\ Soonchunyang Univ. Graduate School of Forensic Science, Asan 336-745, Korea \\ ${ }^{1}$ Scientific Investigation Section, Gyungnam Provincial Police Agency, Changwon 641-797, Korea \\ ${ }^{2}$ Department of Scientific Investigation, National Police Agency, Seoul 120-704, Korea \\ (Received February 28, 2012; Revised May 25, 2012; Accepted June 4, 2012)

\section{시아노아크릴레이트 진공 훈증법에 의한 잠재지문 현출 최적화에 관한 연구}

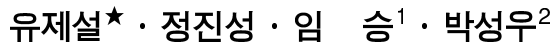 \\ 순천향대학교 법과학대학원, ${ }^{1}$ 경남지방경찰청 과학수사계, ${ }^{2}$ 경찰청 과학수사센터 \\ (2012. 2. 28. 접수, 2012. 5. 25. 수정, 2012. 6. 4. 승인)
}

\begin{abstract}
Cyanoacrylate fuming mehod is effective for latent fingerprints developing on non-porous surfaces. In this study, we investigated optimal conditions for latent fingerprint development using cyanoacrylate fuming method in vacuum chamber. The effects of temperature, relative humidity, fuming method and processing time were checked throughly. The amount of evaporated cyanoacrylate was increased at higher temperature, but cyanoacrylate polymerization on the fingerprint ridge was best at $30{ }^{\circ} \mathrm{C}$. With a relative humidity of $40 \%$ to $50 \%$ conditions, good quality of fingerprints were developed. If a relative humidity is lower than $30 \%$ or higher than $60 \%$, polymerization rate of cyanoacrylate monomers on the fingerprint ridge was decreased. It was identified that application of OMEGA-PRINT ${ }^{\mathrm{TM}}$ dispersal pad or cotton ball with sodium hydroxide fuming method in vacuum chamber was more effective than natural fuming method. We found that cyanoacrylate processing time in vacuum chamber did not have more significant than relative humidity.

요 약: 시아노아크릴레이트 훈증법은 비다공성 표면에 유류된 잠재지문을 현출할 때 효과적이다. 본 연 구는, 진공챔버에서 시아노아크릴레이트를 훈증할 때 온도, 습도, 훈증 방법 등이 잠재지문 현출에 미치는 영향을 확인한 후 최적 반응 조건을 찾는데 있다. 진공챔버의 온도가 높을수록 시아노아크릴레이트 증발 량은 증가했지만, 지문 융선에서 시아노아크릴레이트의 중합반응은 $30{ }^{\circ} \mathrm{C}$ 에서 가장 잘 일어났다. 상대습도 가 $40 \%, 50 \%$ 조건에서는 좋은 상태의 지문이 현출되었지만, $30 \%$ 보다 낮거나 $60 \%$ 보다 높은 조건에서는 지문 융선에서 시아노아크릴레이트 중합반응 속도가 느려졌다. 진공챔버에서 시아노아크릴레이트를 자연 적으로 증발시키는 방법보다는 OMEGA-PRINT ${ }^{\mathrm{TM}}$ dispersal pads와 수산화나트륨을 포함한 솜을 이용해 시 아노아크릴레이트 훈증하는 방법이 효과적이란 사실을 확인할 수 있었다. 진공챔버에서 시아노아크릴레이 트 처리시간은 상대습도에 비해 큰 영향을 주지 않았다.
\end{abstract}

Key words: cyanoacrylate, latent fingerprint, vacuum chamber, temperature, relative humidity

Corresponding author

Phone : +82-(0)41-530-4928 Fax : +82-(0)41-530-4755

E-mail : haplf@naver.com 


\section{1. 서 론}

DNA 프로파일링과 같은 기법의 발전에도 불구하고 지문은 아직까지도 범죄현장에서 신원을 확인하는데 가장 유용한 방법으로 평가되고 있다. ${ }^{1}$ 잠재지문 현출 은 지문 분비물의 화학적 구성 성분에 의해 크게 좌 우되는데, 지문 분비물의 $98 \%$ 이상은 물이며 그 외 왁스, 지방, 지방산, 단백질, 아미노산 그리고 무기물 등으로 구성되어 있다. ${ }^{2-5}$

범죄 현장에서 잠재지문을 찾아내고 증강하는데 분말, 닌히드린, 1,8-diaza-9-fluorenone (DFO), 피지 컬디벨로퍼(PD)등과 같은 다양한 시약들이 사용되고 있지만, ${ }^{6-9}$ 플라스틱, 금속, 유리, 비닐 등과 같은 비 다공성 증거물에 유류되어 있는 잠재지문을 현출할 때는 시아노아크릴레이트가 가장 효과적이라고 알려 져 있다. ${ }^{1,10-13}$

시아노아크릴레이트는 1978년에 일본 경찰청에서 잠재지문을 현출할 때 처음 사용한 이후로 현재까지 가장 많이 사용되고 있는 시약이다. 액체 상태의 시아 노아트릴레이트가 단량체 상태로 증발해 지문 분비물 과 반응하여 흰색의 딱딱한 중합체가 만들어져 잠재 지문 융선이 보이게 되는 원리를 이용한다. ${ }^{11,13,14}$ 지문 분비물과 시아노아크릴레이트 간의 중합반응 기작은 정확히 알려져 있지 않지만 Allison 등에 의해 몇 가 지 모델이 제시되기도 했다. ${ }^{15-17}$ 지문 융선에서 시아노 아크릴레이트 중합반응에 수분이 가장 큰 역할을 담 당하고 있다고 알려져 있지만 Dadmun은 2009년에 작 성한 보고서에서 수분보다는 젖산염과 같은 이온들이 주요 개시제일거란 가능성을 제시했다. ${ }^{15}$

상온에서 증거물이 시아노아크릴레이트 증기에 장 시간 노출될 경우 증거물 표면에서 원하지 않는 과도 한 중합이 일어나 현출된 지문의 contrast가 문제될 수 있다. 이에 대한 해결책으로서 Kendall과 Rehn는 솜과 수산화나트륨을 사용해 시아노아크릴레이트를 빠른 속도로 증발시키는 방법을 발표했고, 다른 연구자들은 열을 이용해 시아노아크릴레이트의 증발 속도를 높이 는 방법을 제안했다. ${ }^{18}$ 최근에는 시아노아크릴레이트 를 보다 효과적으로 증발시켜 지문의 contrast를 높일 목적으로 온도와 습도 조절이 가능한 장비와 진공을 이용한 장비가 사용되고 있다. 온도와 습도 조절이 가 능한 장비는 가열기를 이용해 시아노아크릴레이트의 증발 속도를 조절하여 과도한 증발을 억제하고 해로 운 시아노아크릴레이트 분해물의 생성을 막아준다. 또 한, 습도 조절이 가능하므로 최적의 습도 조건에서 잠
재지문을 현출할 수 있도록 해준다. ${ }^{2}$ 진공을 이용한 장비를 사용하면 상태가 매우 좋은 지문이 현출되며 지문 이외의 증거물 표면에서 중합반응은 거의 일어 나지 않으므로 contrast가 뛰어난 지문을 현출해 낼 수 있다. 시아노아크릴레이트 증기는 상압 조건에서보다 는 $1 \mathrm{mmHg}$ 이하의 진공 조건에서 매우 빠르게 확산 되므로 지문 현출장비 내부의 공기를 강제적으로 순 환시킬 필요가 없다는 장점이 있다. 물론, 진공 방식 으로 현출된 잠재지문은 반투명해 사진 촬영이 쉽지 않기 때문에 로다민 $6 \mathrm{G}$ 등과 같은 형광 염료를 사용 하여 다시 증강시켜야 한다. ${ }^{12,19,20}$ Bessman 등은 습도 조절 방식과 진공 방식의 장비를 사용해 동일한 재질 의 증거물에 유류된 잠재지문을 현출할 때 재질에 따 라 현출된 지문의 상태는 각각 다르지만, 진공 장비로 현출된 지문은 온도, 습도 방식으로 현출된 지문보다 융선이 선명하고 지문 이외의 증거물 표면에서 원하 지 않는 중합반응이 거의 일어나지 않는다고 보고하 였다. ${ }^{2}$

이전의 연구들에서는 진공 조건에서 현출된 지문과 가열 방식으로 현출된 지문을 비교해 진공장비의 사 용 가능성을 제시했을 뿐 진공 조건에서 잠재지문 현 출 최적화에 대한 연구는 수행하지 않았다. 이런 사실 들을 토대로 본 연구에서는 온도와 습도 조절이 까다 로운 고 진공 장비 대신에 주변에서 쉽게 구할 수 있 는 저 진공 장비를 사용하여 온도와 습도, 시아노아크 릴레이트 증발 방법 등이 잠재지문 현출에 미치는 영 향을 확인했고, 잠재지문 현출에 필요한 최적 조건을 찾아냄으로서 대용량의 진공 장비 개발 시에 기초 자 료로 활용하고자 했다.

\section{2. 실험방법}

\section{1. 시약 및 장비}

본 실험에서 잠재지문을 현출할 때 사용한 시아노 아크릴레이트는 Axia 025 Gold (Axia, Korea)로서 ethyl cyanoacrylate 함량이 $96 \%$, 기타 성분이 $4 \%$ 인 제품이 다. 훈증 방식에 의해 잠재지문의 현출 정도를 확인하 기 위해 OMEGA-PRINT ${ }^{\mathrm{TM}}$ dispersal pads (Sirchie, USA) 와 수산화나트륨을 포함한 솜을 사용했으며, 수산화나 트륨을 포함한 솜은 3\% (w/v)의 수산화나트륨 수용액 에 솜을 담군 후 꺼내 상온에서 완전히 건조시켜 제 조하였다. 진공 챔버 내의 습도 변화를 확인하기 위해 KS-201 온습도계(Lavisen, China)를 사용했으며 장비 의 오차율은 온도 $\pm 2{ }^{\circ} \mathrm{C}$, 습도 $\pm 8 \%$ 이다. 잠재지문을 
현출할 때 진공챔버 내의 온도를 조절하기 위해 VS $1202 \mathrm{D} 3 \mathrm{~N}$ 건조오븐(Vision, Korea)를 사용했고, 진공 조건을 만들기 위해 사용한 SF-2100(Gwell, Korea)는 시중에서 판매되는 주방용 가전제품으로서 챔버의 체 적이 약 $2 \mathrm{~L}$, 최대 진공도는 $320 ~ 400 \mathrm{mmHg}$ 정도이다.

\section{2. 진공 상태에서 시아노아크릴레이트 증발량}

진공챔버의 온도에 따라 시아노아크릴레이트를 담 은 용기의 단위면적 $\left(\mathrm{cm}^{2}\right)$ 에서 시간 당 증발하는 시아 노아크릴레이트량과 챔버의 단위체적 (L) 당 증발할 수 있는 최대 양을 확인하기 위해, 표면적이 $7.4 \mathrm{~cm}^{2}$ 인 플라스틱 용기에 $2 \mathrm{~g}$ 의 시아노아크릴레이트를 넣 은 후 진공챔버 안에 넣고 진공을 걸었다. $30{ }^{\circ} \mathrm{C}, 40$ ${ }^{\circ} \mathrm{C}, 50{ }^{\circ} \mathrm{C}$ 로 설정한 건조오븐에 진공챔버를 넣고 30 분 단위로 꺼내 증발한 시아노아크릴레이트량을 측정 하였다. 1 시간 동안 증발한 총 시아노아크릴레이트량 을 용기의 표면적으로 나눈 값을 시간 당 단위면적에 서 증발한 시아노아크릴레이트량으로, 해당 온도에서 더 이상 증발이 일어나지 않는 시간에 측정된 시아노 아크릴레이트 증발량을 진공 챔버의 체적으로 나눈 값을 단위체적에서 증발할 수 있는 최대 시아노아크 릴레이트량으로 정의하였다. 3 회 측정 후 평균값을 사 용하였다.

\section{3. 지문 유류 및 현출 정도 평가}

$\mathrm{OHP}$ 필름 및 매끄러운 플라스틱 표면에 지문을 유 류한 후 실온에서 24시간 동안 보관한 후 실험에 사 용하였으며, 지문이 유류된 각각의 증거물들은 실험 직전에 반으로 나눠서 서로 다른 조건에서 현출한 후, 현출된 지문의 상태를 비교하였다. 현출된 지문 융선 에서 특징점이 12 개 이상 관찰될 경우 개인식별이 가 능하므로, 현출된 지문의 상태는 특징점, 지문 융선의 선명도, 지문 융선에서 시아노아크릴레이트 중합 정도 를 기준으로 하였으며 현출된 지문 융선이 육안 상 선명하면서 특징점 관찰이 용이할수록 상태가 좋은 지문으로 판단하였다.

\section{4. 온도 조건이 지문 현출에 미치는 영향}

진공챔버를 사용해 시아노아크릴레이트로 잠재지문 을 현출할 때 챔버 내 온도 조건이 현출에 미치는 영 향을 확인하고자, 지문이 유류된 $\mathrm{OHP}$ 필름과 시아노 아크릴레이트 $2 \mathrm{~g}$ 을 담은 표면적이 $7.4 \mathrm{~cm}^{2}$ 인 플라스 틱 용기를 진공챔버에 같이 넣은 후 진공을 걸고 20 ${ }^{\circ} \mathrm{C}, 30{ }^{\circ} \mathrm{C}, 40{ }^{\circ} \mathrm{C}, 50{ }^{\circ} \mathrm{C}$ 로 설정한 건조오븐에서 1 시
간 동안 반응시켰다. 각각의 온도 조건에서 현출된 지 문을 촬영했다. 객관적인 비교를 위해 동일 실험을 반 복하였다.

\section{5. 습도 조건이 지문 현출에 미치는 영향}

습도 조건이 지문 현출에 미치는 영향을 확인하고 자, 시아노아크릴레이트 $2 \mathrm{~g}$ 을 담은 표면적이 $7.4 \mathrm{~cm}^{2}$ 인 플라스틱 용기와 지문이 유류된 $\mathrm{OHP}$ 필름을 진공 챔버에 넣은 후 진공을 걸고 $30{ }^{\circ} \mathrm{C}$ 로 설정한 건조오 븐에서 1 시간 동안 반응시켰다. 반응 시 진공챔버 내 의 습도는 $30 \% \sim 70 \%$ 로 유지시켰고, 실험 조건에 맞추 기 위해 증류수를 담은 용기를 같이 넣어 챔버 내의 습도가 자연적으로 높아지도록 설계하였다. 증거물을 넣지 않은 진공챔버에 증류수 $10 \mu \mathrm{L}, 20 \mu \mathrm{L}, 40 \mu \mathrm{L}$, $60 \mu \mathrm{L}$ 와 온습도계를 같이 넣고 진공을 걸어 $30{ }^{\circ} \mathrm{C}$ 로 설정한 건조오븐에서 1 시간 동안 보관한 후 진공챔버 내부의 습도 변화를 확인하여 사용할 증류수의 양을 결정하였다.

\section{6. 진공 챔버 내 훈증 방법이 지문 현출에 미치는 영향}

OMEGA-PRINT ${ }^{\mathrm{TM}}$ dispersal pads와 수산화나트륨을 포함한 솜을 사용해 단위체적 당 시아노아크릴레이트 증발량을 높인 후 진공챔버의 장점인 공간 내 시아노 아크릴레이트의 빠른 확산을 접목해봄으로서 진공챔 버의 단점인 지문의 선명도와 잠재지문 현출 속도가 개선되는지를 확인했다. OHP 필름에 유류한 지문을 반으로 나눈 후 각각의 방법으로 현출된 지문과 진공 만을 이용해 현출된 지문의 상태를 비교했다. 반응시 간은 모두 1 시간이었다. 3 가지 훈증 방법을 사용했으 며, $2 \mathrm{~g}$ 의 시아노아크릴레이트를 표면적이 $7.4 \mathrm{~cm}^{2}$ 인 플라스틱 용기에 담아 자연적으로 증발시키는 방법, OMEGA-PRINT $^{\mathrm{TM}}$ dispersal pads에 시아노아크릴레이 트를 $1 \mathrm{~g}$ 떨어뜨린 후 증발시키는 방법, 수산화나트륨 을 포함한 솜에 시아노아크릴레이트 $1 \mathrm{~g}$ 을 떨어뜨려 증발시키는 방법이었다. 실험할 당시의 실내 온도는 $20{ }^{\circ} \mathrm{C}$, 습도는 $20 \%$ 였다.

\section{7. 진공 처리시간에 따른 지문 현출}

진공챔버 내에서 시아노아크릴레이트 처리시간에 따라 현출되는 지문의 상태 변화를 확인하기 위해 매 끄러운 플라스틱에 유류시킨 잠재지문을 사용했다. 지 문이 유류된 플라스틱과 시아노아크릴레이트 $2 \mathrm{~g}$ 을 담은 표면적 $7.4 \mathrm{~cm}^{2}$ 의 용기를 진공챔버에 같이 넣은 


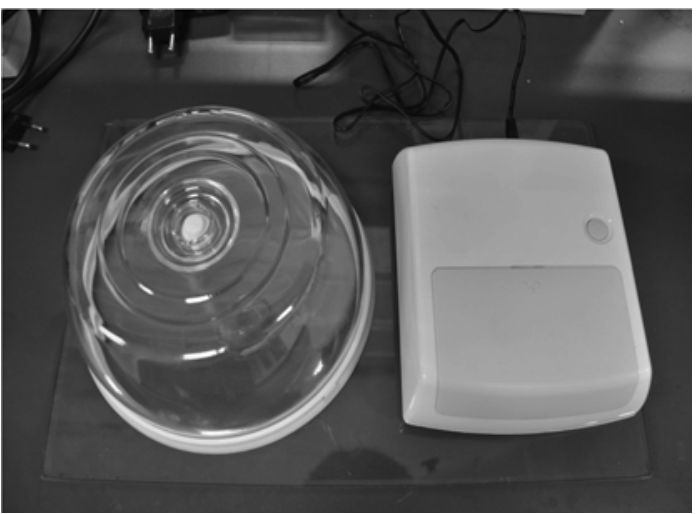

Fig. 1. Photograph of SF-2100.

후 진공을 걸고 $30{ }^{\circ} \mathrm{C}$ 로 설정한 건조오븐에 보관하였 다. 1 시간, 3 시간, 10 시간 경과했을 때 플라스틱을 꺼 내 현출된 지문을 촬영했고, 촬영을 끝낸 후에는 동일 한 방법으로 진공을 걸어 실험을 지속하였다. 실험할 당시의 진공챔버 내의 습도는 $20 \%, 50 \%$ 였다.

\section{3. 결과 및 고찰}

\section{1. 진공 상태에서 시아노아크릴레이트 증발량}

Fig. 2는 진공챔버를 사용할 때 각각의 온도에서 시 간 당 단위면적 $\left(\mathrm{cm}^{2}\right)$ 에서 증발하는 시아노아크릴레이 트량를 보여준다. 시아노아크릴레이트 증발량은 온도 에 비례하지 않았고, $30{ }^{\circ} \mathrm{C}$ 에서 $0.0027 \mathrm{~g} / \mathrm{cm}^{2} \cdot \mathrm{hr}, 40$ ${ }^{\circ} \mathrm{C}$ 에서 $0.0041 \mathrm{~g} / \mathrm{cm}^{2} \cdot \mathrm{hr}, 50{ }^{\circ} \mathrm{C}$ 에서는 $0.0108 \mathrm{~g} / \mathrm{cm}^{2} \cdot \mathrm{hr}$ 를 나타냈다. 단위체적 $(\mathrm{L})$ 당 각각의 온도에서 증발 할 수 있는 최대량은 단위면적에서 시간 당 증발하는

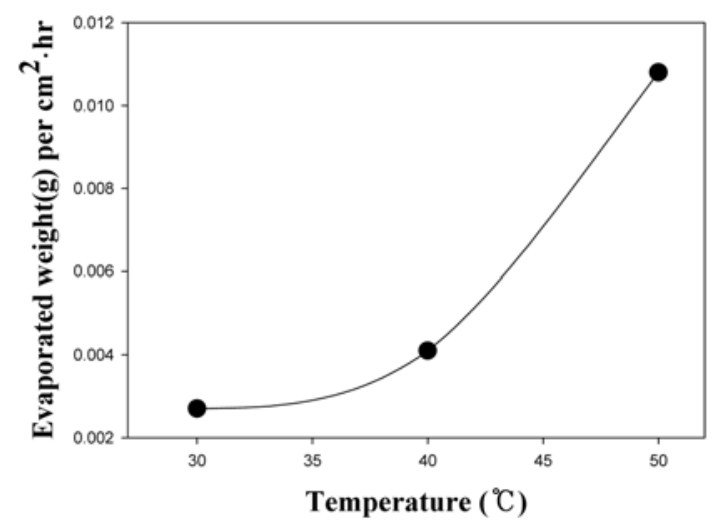

Fig. 2. The amount of evaporated cyanoacrylate on the unit area $\left(\mathrm{cm}^{2}\right)$ of cyanoacrylate loading dish per hour at various temperature in vacuum chamber.

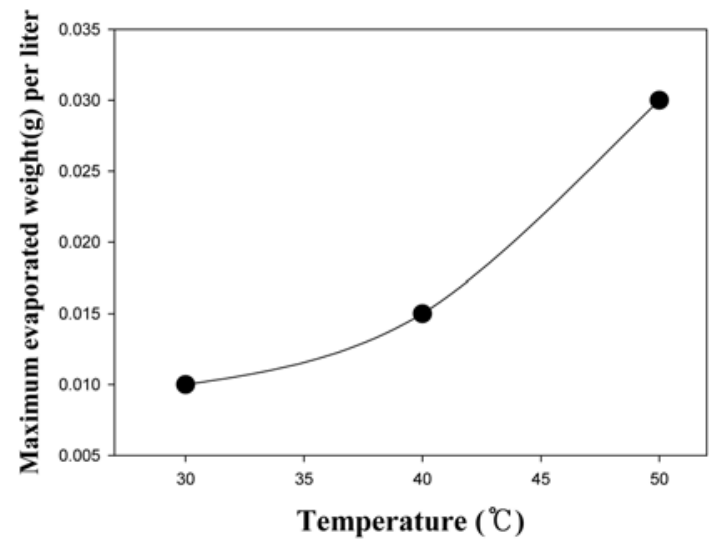

Fig. 3. The maximum amount of evaporated cyanoacrylate per the unit volume (L) at various temperature in vacuum chamber.

양과 비슷한 경향을 나타냈는데 이를 Fig. 3에 나타냈 다. 그림에서 알 수 있듯이, $50{ }^{\circ} \mathrm{C}$ 에서 증발할 수 있 는 시아노아크릴레이트량은 $30{ }^{\circ} \mathrm{C}$ 에서 증발량보다 약 3 배 정도 많았다. 상기 결과들을 토대로, 시아노아크 릴레이트를 증발시키는 용기의 표면적과 진공챔버 온 도가 증발량과 증발속도에 영향을 주는 인자라는 것 을 확인할 수 있었다.

\section{2. 온도에 의한 영향}

Fig. 4는 진공챔버의 온도 조건에 따라 현출된 지문 의 상태를 보여준다. $20{ }^{\circ} \mathrm{C}$ 에서 현출된 지문은 융선의 선명도 및 융선에서 시아노아크릴레이트의 중합 정도 가 다른 온도에서 현출된 지문과 큰 차이를 보였지만, $30{ }^{\circ} \mathrm{C} \sim 50{ }^{\circ} \mathrm{C}$ 조건에서 현출된 지문들은 비슷했다. 진 공챔버의 온도가 높을수록 단위체적 당 증발할 수 있 는 시아노아크릴레이트량 또한 증가한다. $30{ }^{\circ} \mathrm{C}$ 보다 $50{ }^{\circ} \mathrm{C}$ 조건에서 반응에 참여할 수 있는 시아노아크 릴레이트량이 3 배 정도 많지만 $30{ }^{\circ} \mathrm{C} \sim 50{ }^{\circ} \mathrm{C}$ 조건 에서 현출된 지문의 상태가 비슷하다는 것은 지문 융선에서 시아노아크릴레이트의 중합반응은 $30{ }^{\circ} \mathrm{C}$ 에 서 보다 잘 이루어졌음을 의미한다. 이 결과는 지문 융선에서 시아노아크릴레이트의 중합반응은 온도가 낮을수록 증가한다는 Dadmun의 실험 결과 ${ }^{13}$ 와 유사 하다. 즉, 시아노아크릴레이트와 지문 분비물 간의 반응특성은 사용한 훈증 방식에 의해 변하지 않는다 는 것을 알 수 있다. $20{ }^{\circ} \mathrm{C}$ 조건에서 현출된 지문의 상태가 좋지 않았던 것은 반응에 필요한 충분한 양 의 시아노아크릴레이트가 증발되지 않았기 때문이라 고 추정된다. 


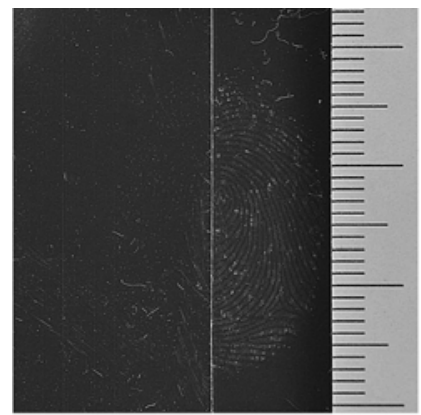

(a)

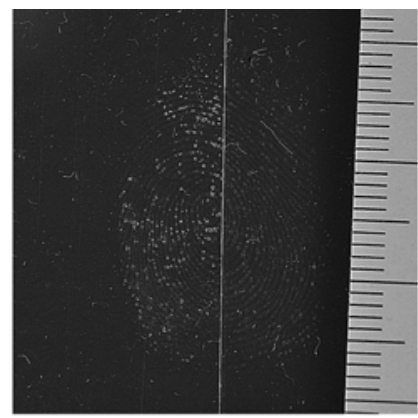

(b)

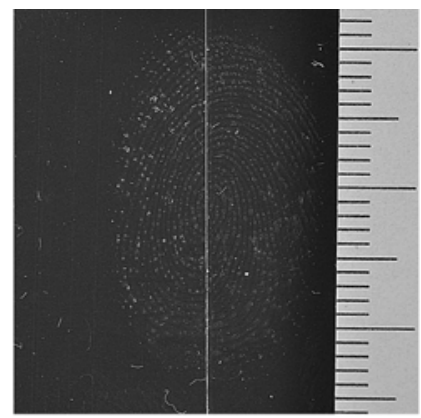

(c)

Fig. 4. Effect of temperature for the polymerization of cyanoacrylate on the latent fingerprint ridge in vacuum chamber. (a) 20 ${ }^{\circ} \mathrm{C} / 30{ }^{\circ} \mathrm{C}$, (b) $30{ }^{\circ} \mathrm{C} / 40{ }^{\circ} \mathrm{C}$, (c) $40{ }^{\circ} \mathrm{C} / 50{ }^{\circ} \mathrm{C}$.

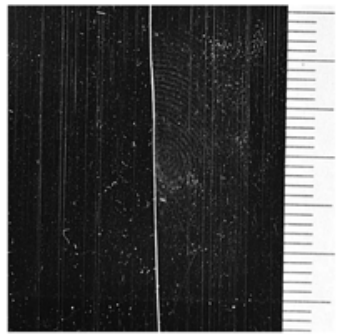

(a)

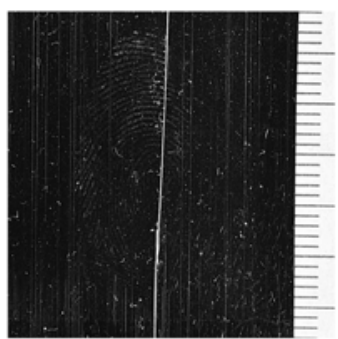

(c)

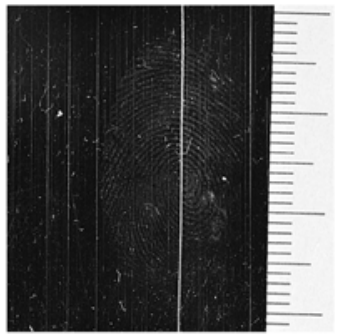

(b)

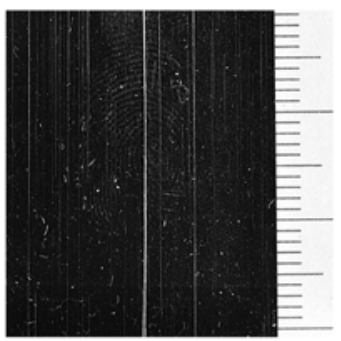

(d)
Fig. 5. Effect of relative humidity for the polymerization of cyanoacrylate on the latent fingerprint ridge in vacuum chamber. (a) $30 \% / 40 \%$, (b) $40 \% / 50 \%$, (c) $50 \% / 60 \%$, (d) $60 \% / 70 \%$.

\section{3. 습도에 의한 영향}

진공챔버를 사용할 때 챔버 내의 습도 조건이 시아 노아크릴레이트로 현출된 지문의 상태에 미치는 영향 을 검토했고, 그 결과를 Fig. 5에 나타냈다. 진공챔버 내에는 별도의 습도 조절 장치가 없으므로 온도 최적 조건이었던 $30{ }^{\circ} \mathrm{C}$ 에서 자연적으로 증발하는 증류수 양을 고려해 적용하였다. 그림에 보이듯이, 현출되는 지문의 상태는 습도 $40 \% \sim 50 \%$ 조건에서 가장 좋았다. 물론, $30 \%$ 이하, $60 \%$ 이상 조건에서도 지문 융선에 서 시아노아크릴레이트 중합반응이 관찰되긴 했지만
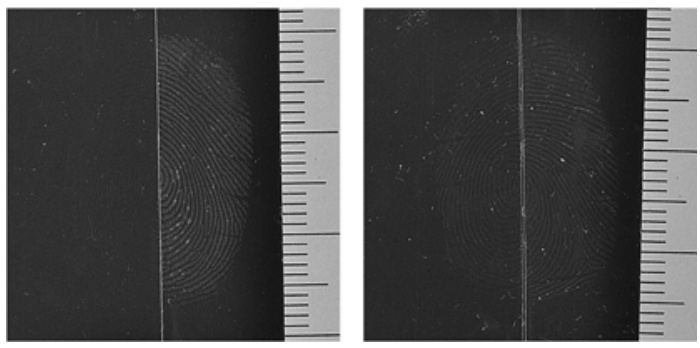

Fig. 6. Effect of cyanoacrylate fuming method for the polymerization of cyanoacrylate on the latent fingerprint ridge in vacuum chamber. (a) normal vacuum method/ OMEGA-PRINT $^{\mathrm{TM}}$ dispersal pads loading method, (b) OMEGA-PRINT ${ }^{\mathrm{TM}}$ dispersal pads loading method/ cotton ball with sodium hydroxide method.

사진 촬영에 적합하지는 않았다. 이런 결과는 지문 융 선에서 시아노아크릴레이트 중합반응은 습도 $50 \%$ 조 건에서 잘 이루어진다는 Dadmun의 실험 결과 ${ }^{13}$ 와 유 사하다. 진공챔버 내의 온도와 진공도에 따라 습도가 달라지겠지만, 진공챔버와 시아노아크릴레이트를 이 용하여 잠재지문을 현출해 내기 위해서는 습도 역시 고려되어야 하는 인자라는 것을 알 수 있었다.

\section{4. 훈증 방법에 따른 지문 현출}

낮은 온도 습도 조건에서 진공챔버 방식을 사용할 경우에, 증거물에 유류된 잠재지문을 짧은 시간 내에 선명하게 현출해 낼 수 없다는 사실을 실험을 통해 확인하였다. 저 진공챔버는 온도 습도 조절이 쉽지 않 기 때문에 실험할 당시의 외부 환경에 영향을 받기 쉽다. 동일한 온도 습도 및 진공 조건에서 시아노아크 릴레이트를 자연적으로 증발시키는 방법과 수산화나 트륨을 포함한 솜과 OMEGA-PRINT ${ }^{\mathrm{TM}}$ dispersal pads 를 사용해 증발량을 강제적으로 높이는 방법을 사용 


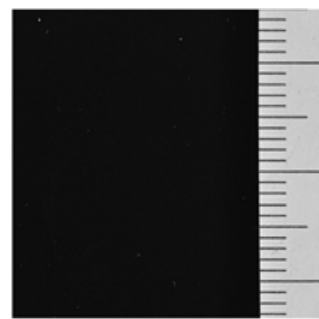

(a)

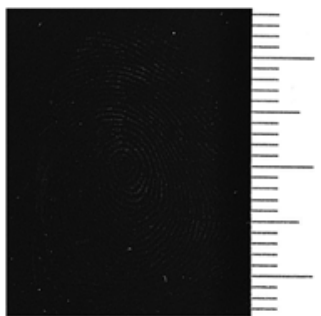

(b)

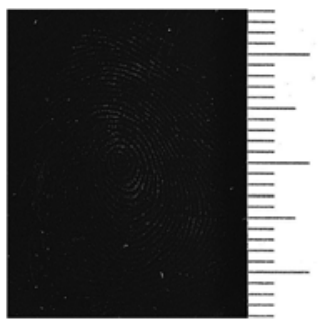

(c)

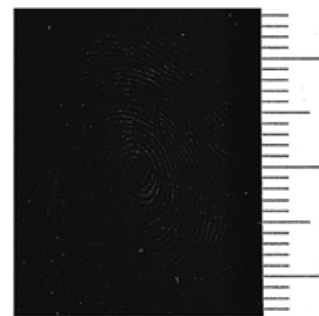

(d)

Fig. 7. Development of latent fingerprint on plastic surface using cyanoacrylate fuming method in vacuum chamber by processing time at $30{ }^{\circ} \mathrm{C}$, RH 20\%. (a) $0 \mathrm{hrs,} \mathrm{(b)} 1 \mathrm{hrs}$, (c) $3 \mathrm{hrs}$, (d) $10 \mathrm{hrs}$.

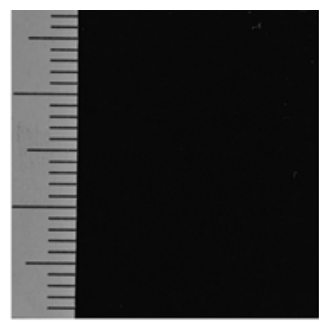

(a)

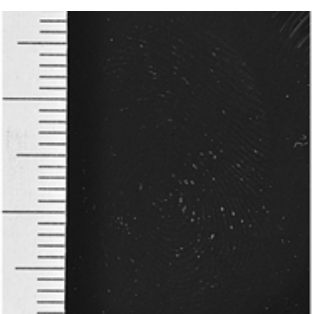

(b)

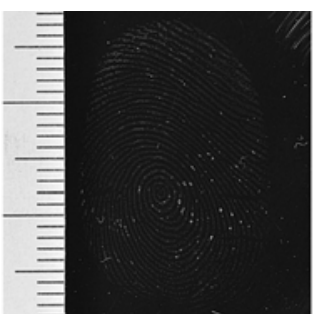

(c)

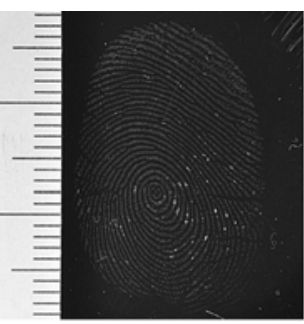

(d)

Fig. 8. Development of latent fingerprint on plastic surface using cyanoacrylate fuming method in vacuum chamber by processing time at $30{ }^{\circ} \mathrm{C}$, RH 50\%. (a) 0 hrs, (b) 1 hrs, (c) 3 hrs, (d) 10 hrs.

했을 때 현출된 지문을 Fig. 6에 나타냈다. 그림에 보이 듯이, 강제적으로 증발량을 높이는 방법으로 현출된 지 문의 상태가 진공 조건에서 시아노아크릴레이트를 자 연적으로 증발시켜 현출된 지문의 상태보다 좋았다. 강 제적으로 증발량을 높이는 방법으로 현출된 지문은 지 문 융선 전반에 걸쳐 동일한 수준의 중합이 일어났고 융선의 특정 부분에서 과도한 중합이 관찰되지 않았는 데, 진공 상태에서 시아노아크릴레이트의 빠른 확산에 의한 결과로 판단되었다. 자연적인 증발 방법을 사용해 현출한 지문의 상태는 좋지 않았는데, 실험할 당시의 실내 온도와 습도가 각각 $20{ }^{\circ} \mathrm{C}, 20 \%$ 였으므로, 온도가 낮아 시아노아크릴레이트 증발량이 충분하지 못했고 습도도 현출에 부적절했기 때문에 발생한 결과로 추정 된다. 진공챔버를 사용할 때 현출된 지문의 상태를 개 선하기 위해서는 온도 습도 조건과는 별개로 챔버 내 에서 시아노아크릴레이트 증발량을 강제적으로 높이는 방법을 적용하는 것이 가장 좋다고 판단하였다.

\section{5. 처리시간에 따른 영향}

진공챔버 내의 습도 조건에 따라 현출되는 지문의 상태가 변한다는 사실을 실험을 통해 확인하였다. 진 공챔버 내의 습도가 낮을 경우에는 지문 융선에서 시 아노아크릴레이트의 중합반응이 매우 느리게 진행되
었고, 2 3시간이 경과한 후에는 지문 융선에서 더 이 상의 중합반응이 관찰되지 않았다(Fig. 7). 그에 반해, 습도가 비교적 높았던 $50 \%$ 조건에서는 지문 융선에 서 시아노아크릴레이트 중합반응이 $20 \%$ 조건에서 보 다 빠르게 진행되었다. 그렇지만, $20 \%$ 조건에서처럼 3 시간 이상이 경과 했을 때부터는 처리시간에 비해 융선의 선명도가 뚜렷하게 개선되지 않았다(Fig. 8). 진공챔버 내의 습도는 지문 융선에서 시아노아크릴레 이트의 초기 중합반응 속도에 영향을 주는 인자로서 지문 융선에서 시아노아크릴레이트가 지속적으로 반 응할 때 관여되는 인자는 아닌 것으로 추정된다. 처리 시간에 따른 결과를 토대로, 잠재지문을 현출할 때 진 공챔버를 사용하면 시아노아크릴레이트 증기에 증거물 이 장시간 노출되어도 증거물에 유류된 지문 융선에서 과도한 중합반응이 일어나지 않을 것이므로 상태가 좋 은 지문을 현출해 낼 가능성이 높다고 판단된다.

\section{4. 결 론}

기체의 확산속도를 높여 공간 내 농도 균일화를 만 들어주는 진공챔버를 시아노아크릴레이트 훈증에 적 용하는 것은 온도 습도 조절이 가능한 챔버를 사용하 는 방식에 비해 지문 융선 이외에 증거물 표면에서 
시아노아크릴레이트의 과도한 중합반응을 막아줌으로 서 contrast를 높여준다는 장점이 있다.

본 실험에서는 시아노아크릴레이트와 진공챔버를 이용해 잠재지문을 현출 할 때 관련된 인자를 파악한 후 최적 조건에서 잠재지문을 현출하고자 했다. 진공 챔버 내부의 온도가 상승할수록 시아노아크릴레이트 증발량 역시 증가했는데, $30{ }^{\circ} \mathrm{C}$ 이상의 조건에서 현출 된 지문의 상태는 모두 비슷하였다. 즉, 반응 후에 현 출된 지문의 상태는 진공챔버 내의 시아노아크릴레이 트의 농도보다는 온도에 영향을 받는다고 생각된다. 온도와 달리 습도는 현출된 지문의 상태에 비교적 큰 영향을 미쳤고, 습도가 $30 \%$ 보다 낮거나 $60 \%$ 보다 높은 조건에서는 지문 융선에서 시아노아크릴레이트 의 중합반응 속도가 매우 느려졌다. 진공챔버는 습도 를 낮춰주므로 진공챔버를 사용해 지문을 현출할 경 우에는 시아노아크릴레이트 중합에 필요한 $40 \%$ $50 \%$ 의 습도를 유지할 수 있는 추가적인 방법을 고려 해야 할 것이다.

진공챔버 내에서 시아노아크릴레이트가 지문 융선 에 반응 해 상태가 좋은 지문이 현출되기 위해서는 진공챔버 내의 시아노아크릴레이트 농도가 중요했는 데, 이를 위해 수산화나트륨을 포함한 솜과 OMEGAPRINT $^{\mathrm{TM}}$ dispersal pads 등을 사용할 수 있다. 다량의 시아노아크릴레이트가 짧은 시간에 증발했지만 진공 챔버 내에서의 빠른 확산 때문에 지문 융선에서 균일 한 정도의 중합반응이 이루어졌고 상태가 좋은 지문이 현출되었다. 진공챔버를 이용해 잠재지문을 현출할 때 필요한 시간을 줄이고 육안으로 선명한 지문을 현출하 기 위해서는 온도 습도 조절과 함께 강제적인 증발 방 법의 사용도 고려해 봐야 할 것이다. 진공챔버 내에서 시아노아크릴레이트 처리시간은 현출된 지문의 상태 에 큰 영향을 주지 않는 것으로 보였고, 습도가 높을 경우에는 반응 초기에 지문 현출 속도가 빨라져 융선 의 선명도가 증가했고 습도가 낮을 경우엔 반응이 매 우 느리게 진행되었다. 진공챔버의 습도 조건에 따라 현출된 지문의 상태가 결정되었다. 물론, 습도 조건에 관계없이 반응은 3 시간 이내에 대부분 완료되었고 이 후에는 지문 융선에서 더 이상의 중합은 관찰되지 않 았다. 본 실험에서는 저 진공 장치를 이용해 온도, 습 도, 증발 방식, 처리 시간 등이 현출되는 지문의 상태 에 미치는 영향을 확인했지만 장비의 진공도가 현출 된 지문의 상태에 미치는 영향은 고려하지 않았다. 차 후 실험에서는 지문 현출에 필요한 최적의 조건에서 진공챔버의 진공도가 잠재지문 현출에 미치는 영향에
대한 추가연구가 필요할 것으로 생각된다.

\section{참고문헌}

1. C. Lennard, 13th INTERPOL Forensic Science Symposium, Lyon, France, 86-93 (2001).

2. H. C. Lee and R. E. Gaensslen, 'Advances in Fingerprint Technology', 2nd Ed., CRC Press, Boca Ration, 2001.

3. J. Siegel, P. Saukko and G. Knupfer, 'Encyclopedia of Forensic Sciences', Academic press, Oxford, 2000.

4. M. J. Choi, Y. S. Sun, C. S. Kim, M. S. Choi, N. D. Sung and S. W. Park, Anal. Sci. Technol., 20(2), 147154 (2007).

5. M. J. Choi, J. H. Ha and S. W. Park, Anal. Sci. Technol., 21(3), 212-221 (2008).

6. O. P. Jasuja, M. A. Toofany, G. Singh and G. S. Sodhi, Science and Justice, 49, 8-11 (2009).

7. G. S. Sodhi and J. Kaur, Forensic science International, 120, 172-176 (2001).

8. A. Rawji and A. Beaudoin, J. Forensic Ident., 56(1), 33-54 (2005).

9. R. J. Jelly, E. L. T. Patton, C. Lennard, S. W. Lewis and K. F. Lim, Analytica Chimica Acta, 652, 128-142 (2009).

10. A. Misner, D. Wilkinson and J. Watkin, J. Forensic Ident., 43(2), 154-165 (1993).

11. A. Czubak, Problems of Forensic Sci., vol. LII, 87-99 (2002).

12. C. W. Bessman, E. Nelson, R. J. Lipert and S. Coldiron, J. Forensic Ident., 55(1), 10-27 (2005).

13. E. R. Menzel, J. A. Burt, T. W. Sinor, W. B. T. Ley and K. J. Jordan, J. Forensic Sci., 28(2), 307-317 (1983).

14. J. Almog and A. Gabay, J. Forensic Sci., 31(1), 250253 (1986).

15. M. D. Dadmun, Final Project Report to the Department of Justice, 1-27 (2009).

16. P. Czekanski, M. Fasola and J. Allison, J. Forensic Sci., 51(6), 1323-1328 (2006).

17. S. P. Wargacki, L. A. Lewis and M. D. Dadmun, $J$. Forensic Sci., 52(5), 1057-1062 (2007).

18. L. A. Lewis, R. W. Smithwick, G. L. Devault, B. Bolinger and S. A. Lewis, J. Forensic Sci., 46(2), 241-246 (2001).

19. A. B. Yamashita, J. Forensic Ident., 44(2), 149-158 (1994).

20. J. E. Watkin, D. A. Wilkinson and A. B. Yamashita, 44(5), 545-556 (1994). 